\title{
FAKTOR PREDISPOSISI DAN PRESTIPITASI PASIEN RESIKO PERILAKU KEKERASAN
}

\author{
Kandar $^{1 *}$, Dwi Indah Iswanti ${ }^{2}$ \\ ${ }^{1}$ RSJD dr. Amino GondohutomoProvinsiJawa Tengah \\ ${ }^{2}$ Stikes Karya Husada Semarang \\ *maskandar31@yahoo.com
}

\begin{abstract}
ABSTRAK
Permasalahan utama yang sering terjadi pada pasien skizofrenia adalah perilaku kekerasan. Kondisi ini harus segera ditangani karena perilaku kekerasan yang terjadi dapat membahayakan diri pasien, orang lain dan lingkungan.Penelitian kualitatif dengan pendekatan kualitatif deskriptif yang bersifat memahami gambaran faktor predisposisi dan presipitasi pada partisipan pasien resiko perilaku kekerasan. Ada 3 Faktor predisposisi pada Pasien dengan Risiko Perilaku Kekerasan di RSJD Dr. Amino Gondohutomo Provinsi Jawa Tengah yaitu : Faktor genetik yang menyebabkan pasien mengalami risiko perilaku kekerasan. Faktor psikologis yang menyebabkan pasien mengalami risiko perilaku kekerasan antara lain yaitu: Kepribadian yang tertutup, Kehilangan, Aniayaseksual, Kekerasandalamkeluarga. Faktor sosial budaya yang menyebabkan pasien mengalami risiko perilaku kekerasan yaitu: Pekerjaan, Pernikahan.Ada 3 Faktor Presipitasi pada Pasien dengan Risiko Perilaku Kekerasan di RSJD Dr. Amino Gondohutomo Provinsi Jawa Tengah yaitu ; Faktor genetik; putus obat sebagai pencetus pasien mengalami risiko perilaku kekerasan. Faktor psikologis yaitu konsep diri sebagai pencetus pasien mengalami risiko perilaku kekerasan. Faktor sosial budaya yaitu ketidakharmonisan lingkungan tempat tinggal membuat diri ingin marah dan berbicara dengan kasar.
\end{abstract}

Kata kunci: predisposisi, presipitasi, resiko perilkau kekerasan

\section{PREDISPOSITION AND PRESTIPITATION FACTORS OF RISK OF VIOLENT BEHAVIOUR}

\begin{abstract}
The main problem that often occurs in patient with schizofrenia is violent behaviour. This condition must be overcome immediately because it could endanger patient itself, others abd the environment. A qualitative research with a descriptive qualitative approach which is understand the image of predisposing and precipitation factors in participant of patient with risk of violent behaviour. There are 3 predisposing factors in patient with risk of violent behaviour at The Mental Hospital of Dr Amino Gondohutomo Central Java Province, that is : Genetic factor, psychological factor such as closed personality, lose experience, sexual abuse, domestic violence and Sociocultural factors that is occupation and marriage. Then the 3 precipitatiobn factors in patient with risk ov violent behaviour are : Genetic factor that is drop out of medicine, Psychological factor that is body concept and Sociocultural factor namely environmental disharmony that makes patient become angry and speak rudely.
\end{abstract}

Keywords: Predisposing, Precipatation, Violent behaviour

\section{PENDAHULUAN}

Kesehatan jiwa adalah kondisi sehat emosional, psikologis dan sosial yang terlihat dari hubungan interpersonal yang memuaskan, perilaku dan koping yang efektif, konsep diri yang positif dan kesehatan emosional (Videbeck, 2008). Menurut WHO memperkirakan 450 juta orang diseluruh dunia mengalami gangguan mental, sekitar $(10 \%)$ orang dewasa mengalami gangguan jiwa saat ini dan (25\%) penduduk diperkirakan akan mengalami gangguan jiwa pada usia tertentu selama hidupnya (WHO, 2009). 
Hasil dari Riset Kesehatan Dasar (RISKESDAS) prevalensi gangguan jiwa berat pada penduduk Indonesia 1,7 per mil, dan gangguan mental emosional pada penduduk Indonesia 6 persen. Gangguan jiwa berat terbanyak di Yogyakarta, Aceh, Sulawesi Selatan, Bali, dan Jawa Tengah. Proporsi rumah tangga yang pernah memasung anggota rumah tangga gangguan jiwa berat 14,3 persen dan terbanyak pada penduduk yang tinggal di perdesaan $(18,2 \%)$, serta pada kelompok penduduk dengan kuintil indeks kepemilikan terbawah (19,5\%). Provinsi dengan prevalensi ganguan mental emosional tertinggi adalah Sulawesi Tengah, Sulawesi Selatan, Jawa Barat, Yogyakarta, dan Nusa Tenggara Timur (Kemenkes RI, 2013).

Jumlah kunjungan gangguan jiwa tahun 2013 di Provinsi Jawa Tengah sebanyak 121.962. Sebagian besar kunjungan gangguan jiwa adalah di rumah sakit $(67,29 \%)$, sedangkan $32,71 \%$ lainnya di Puskesmas dan sarana kesehatan lain (Dinkes Jateng, 2013).Sebagian besar pasien dengan skizofrenia dan gangguan mental tidak dengan kekerasan. Meskipun demikian, risiko kekerasan pada pasien dengan gangguan ini lebih besar dari pada populasi umum. Risiko ini sangat tinggi di skizofrenia dan gangguan mental dengan gangguan penggunaan zat adiktif, ketergantungan alkohol, depresi, dan gangguan kepribadian, bahkan tanpa hal tersebut (Volavka, 2013). Permasalahan utama yang sering terjadi pada pasien skizofrenia adalah perilaku kekerasan. Kondisi ini harus segera ditangani karena perilaku kekerasan yang terjadi dapat membahayakan diri pasien, orang lain dan lingkungan (Saseno \& Kriswoyo, 2013).

Perilaku kekerasan adalah suatu keadaan dimana seseorang melakukan tindakan yang dapat membahayakan secara fisik, baik kepada diri sendiri maupun orang lain (Afnuhazi, 2015). Menurut Erwina (2012) perilaku kekerasan adalah merupakan bentuk kekerasan dan pemaksaan secara fisik maupun verbal ditunjukkan kepada diri sendiri maupun orang lain. Perilaku kekerasan adalah salah satu bentuk perilaku yang bertujuan untuk melukai seseorang secara fisik maupun psikologi (Keliat et al., 2011).

Menurut Kusumawati dan Hartono (2010) kekerasan dianggap sebagai suatu akibat yang ektrem dari marah atau ketakutan atau panik. Perilaku agresif dan perilaku kekerasan sering dipandang sebagai rentang dimana agresif verbal di suatu sisi dan perilaku kekerasan (violence)di sisi yang lain. Suatu keadaan yang menimbulkan emosi, perasaan frustasi, benci atau marah. Hal ini akan mempengaruhi perilaku seseorang. Berdasarkan keadaan emosi secara mendalam tersebut terkadang perilaku menjadi agresif atau melukai karena penggunaan koping yang kurang bagus.

\section{METODE}

Penelitian kualitatif dengan pendekatan kualitatif deskriptif yang bersifat memahami gambaran faktor predisposisi dan presipitasi pada partisipan pasien resiko perilaku kekerasan, dengan analisa data kualitatif colaizzi. Sampel 5 pasien dengan diagnosis keperawatan resiko perilaku kekerasan. Dilakukan penelitian pada bulan Maret 2019 di RSJD dr. Amino Gondohutomo Provinsi Jawa Tengah.

\section{HASIL}

Faktor prediposisi

a. Faktor genetik

Hasil penelitian ini menunjukkan bahwa faktor genetik tidak mempengaruhi partisipan mengalami perilaku kekerasan (RPK). Berdasarkan hasil wawancara bersama kelima pasien RPK di ruang Brotojoyo RSJD Gondohutomo Jawa Tengah pasien mengatakan bahwa"Tidak ada anggota keluarga yang mengalami gangguan jiwa" (R1, R2, R3, R4, dan R5).

\section{b. Faktor psikologis}

Hasil penelitian ini menunjukkan bahwa faktor psikologis yang mempengaruhi partisipan mengalami perilaku kekerasan antara lain:

1) Kepribadian yang tertutup

Partisipan mengungkapkan bahwa memiliki kepribadian yang tertutup merupakan penyebab dari seseorang mengalami gangguan jiwa, kepribadian yang tertutup 
yang tidak pernah mengungkapkan atau menceritakan permasalahannya membuat partisipan menyimpan seluruh beban-beban permasalahan di jiwanya. Partisipan menyatakan sebagai berikut:

"Saya tidak pernah ceritake orang lain mba, karna ga ada yang bisa dipercaya. Akhirnya nggrundel-nggrundel nengati trus numpuknumpuk akhirnya marah, Paijo dan Patimah yang suruh-suruh saya mba." (P1).

\section{2) Kehilangan}

Partisipan mengungkapkan bahwa perasaan kehilangan yang sangat mendalam yang dialami oleh partisipan merupakan penyebab dari seseorang mengalami gangguan jiwa, yang menyebabkan partisipan bisa dirawat di rumah sakit jiwa. Partisipan menyatakan sebagai berikut:

"saya cerai dengan suami pertama mas, setelah itu saya menikah lagi. Tapi berapa tahun kemudian suami saya yang kedua meninggal mas. Rasanya sangat menyakitkan. Saya suka marah-marah keanak-anak" (R3).

\section{3) Aniayaseksual}

Berdasarkan hasil wawancara partisipan mengungkapkan bahwa aniaya seksual menyebabkan pasien mengalami risiko perilaku kekerasan. Partisipan mengatakan sebagai berikut:

"suami pertama saya dulu dating kerumah hanya untuk berhubungan intim setelah selesai suami saya meninggalkan saya mba. Jadi, saya sangat kesal mba. Saya suka bakar barang - barang di rumah dan suka marah - marah. Waktu itu saya berumur 30 tahun."(R3).

4) Kekerasandalamkeluarga

Berdasarkan hasil partisipan wawancara mengungkapkan bahwa partisipan pernah mengalami kekerasan dalam keluarga. Partisipan mengatakan sebagai berikut:

"Waktu itu saya minta uang jajan sama orangtua mba, tapi saya tidak di kasih uang. Saya jadi sering marah -marah mba lalu bapak pukul saya kaki dan paha saya biru. Saya sering berantem sama keluarga" (R2).

c. Faktor sosial budaya

Hasil penelitian ini menunjukkan bahwa faktor sosial budaya yang mempengaruhi partisipan mengalami perilaku kekerasan, yaitu:

1) Pekerjaan

Pada saat dilakukan wawancara pasien mengungkapkan bahwa:

"Dulu saya bekerja berpindah - pindah mba, terakhir saya itu kerja di pabrik jamu, tapi gajinya sedikit. Saya memilih untuk buka toko sendiri. Jualan rokok-rokok, kopi di pinggir jalan. Tempatnya itu saya sewa. Kadang laku kadang juga ngga. Karena capek saya suka marah-marah". (R4)

2) Pernikahan

Pada saat dilakukan wawancara pasien mengungkapka nbahwa:

"Suami saya yang pertama, dia hanya dating untuk berhubungan intim dengan saya. Setelah itu dia pergi meninggalkan saya. Akhirnya saya minta cerai mba. Waktu itu saya berumur 30 tahun. Sejak saat itu saya suka membakar barang - barang di rumah. Kemudian saya menikah lagi, tapi beberapa tahun kemudian suami saya meninggal mba" (R3).

\section{Faktor presipitasi}

a. Faktor genetik

Putus obat sebagai pencetus pasien mengalami risiko perilaku kekerasan. Pasien mengungkapkan bahwa penyebab putus obat disebabkan berbagai faktor, seperti efek samping obat yang membuat pasien pusing, tidak ada yang mengingatkan untuk kontrol dan minum obat serta keinginan untuk tidak mengkonsumsi obat lagi. Partisipan menyatakan sebagai berikut:

"ini perawatan yang kedua kali mba, dulu itu saya tidak kontrol, trus sudah empat bulan saya tidak minum obat mba, akhirnya saya kumat seperti sekarang ini” (R1).

"sudah tiga kali saya di rawat di rumah sakit sini mba. Keluarga saya yang bawa saya kesini.”(R3) 
b. Faktor psikologis

Konsep diri sebagai pencetus pasien mengalami risiko perilaku kekerasan.

"saya merasa tidak terima mba, tanah saya dimiliki oleh tetangga saya. Saya berantem sama tetangga, kadang saya juga suka marah-marah sama anak. Tapi kok saya di bawa kesini mba?" (R5)

c. Faktor social budaya

Partisipan mengungkapkan bahwa konflikv lingkungan yang menjadi stressor dan penyebab seseorang mengalami gangguan jiwa. Ketidakharmonisan membuat diri ingin marah dan berbicara dengan kasar. Partisipan menyatakan sebagai berikut:

"Saat tinggal dirumah lama banyak tetangga saya yang tidak suka sama saya mba. Mereka suka menceritakan saya. Saya jadi suka adu mulut sama mereka yang menceritakan saya mba. Kadang rasanya mau pukul, tapi kalau mau pukul kayak sayang juga mba". (R4)

\section{PEMBAHASAN}

Faktor predisposisi

a. Faktor genetik

Berdasarkan hasil wawancara, tidak terdapat partisipan yang mengungkapkan bahwa ada anggota keluarga yang pernah dirawat di rumah sakit Amino Gondohutomo namun berdasarkan teori Faktor genetik mempunyai peranan dalam terjadinya skizofrenia, meskipun sulit dipisahkan apakah karena faktor genetik atau lingkungan. Kembar identi dipengaruhi oleh gen sebesar 50\% terjadinya skizofrenia, sedangkan kembar monozygot sekitar $40 \%$ dan kembar dizygot pengaruhnya sebesar 1,8 - 4,1\% (Stuart, 2013). Skizofrenia kemungkinan berkaitan dengan kromosom 1,3,5,11 dan koromosom $\mathrm{X}$. penelitian genetic ini dihubungkan dengan COMT (catechol-O-Methyl Transferase) dalam enconding dopamine sehingga mempengaruhi fungsi regulasi dopamine.

Menurut beberapa ahli faktor genetik tidak cukup untuk menurunkan gangguan jiwa pada generasi berikutnya, penyebab terjadinya gangguan jiwa adalah interaksi antar faktor genetik dengan pola asuh yang dikembangkan dalam keluarga (Varcarolis
2010, dalam Wardayani, 2010). Sebuah penelitian tentang "schizophrenia virus" (Moreno et al, 2011) berdasarkan data bahwa paparan virus influenza saat prenatal selama trimester pertama kehamilan memungkinkan menjadi salah satu faktor terjadinya skizofrenia meskipun pada kehamilan yang lain tidak terjadi.

b. Faktor psikologis

1) Kehilangan

Kehilangan adalah suatu keadaan dimana seseorang merasa kekurangan atas ketiadaan sesuatu yang tadinya ada. Kehilangan disebabkan oleh berbagai macam yaitu kehilangan orang yang dicintai, barang maupun pekerjaan. Rasa kehilangan akan menyebabkan seseorang merasa cemas hingga mengalami kecemasan yang berlebihan itulah yang akan menyebabkan seseorang mengalami gangguan kejiwaan (Saputri, 2016). Menurut Potter \& Perry (2005), kehilangan merupakan keadaan seseorang yang mengalami perpisahan dengan sesuatu yang sebelumnya ada menjadi tidak ada. Sedangkan menurut Stuart \& Sudeen (1998), kehilangan merupakan perpindahan keadaan seseorang yang awalnya memiliki dari ada menjadi tidak ada. Seseorang yang mengalami kehilangan, kegagalan dan berduka akan merasakan perasaan yang tidak enak dan tidak nyaman. Perasaan yang berlebihan akan menyebabkan seseorang tertekan dan terganggu kejiwaannya. Perasaan cemas yang berlebihan akan sangat mempengaruhi seseorang mengalami gangguan jiwa dan dapat mengakibatkan terjadinya risiko perilaku kekerasan.

\section{2) Kepribadian}

Menurut Allport (1971 dalam Sobur, 2003) kepribadian adalah organisasi-organisasi dinamis sistem-sistem psikofisik dalam individu yang turut menentukan cara-caranya yang unik/khas dalam menyesuaikan diri dengan lingkungannya. Sedangkan menurut Cattel (1965 dalam Sobur, 2003) kepribadian adalah sesuatu yang menentukan perilaku dalam ketetapan situasi dan kesadaran jiwa. Menurut Stuart (2009) faktor yang mendukung terjadinya risiko perilaku kekerasan yaitu kepribadian tertutup. 
Kebanyakan pasien yang mengalami risiko perilaku kekerasan memiliki tipe kepribadian introvert. Individu dengan tipe kepribadian introvert lebih tertuju kepada tenaga bersifat intuitif dan suka mengkhayal, merenung, dan ragu-ragu dalam mencapai keputusan akhir. Selain itu, orang memiliki tipe kepribadian introvert tidak menyenangi keramaian sehingga tidak hanya datang untuk berkumpul bersama dengan orang lain tetapi lebih punya tujuan tertentu dan ketika menghadiri kegiatan mereka juga terlihat kurang percaya diri sehingga tidak berani dalam bertidak, dan cenderung pemalu (Yanuar, 2012). Menurut Putra (2015) orang dengan kepribadian introvert cenderung hidup dalam dunianya sendiridan kurangnya interaksi dengan dunia luar, memiliki pribadi yang tertutup, sulit untuk bersosialisasi dengan orang lain, dan sering menarik diri dari suasana yang ramai. Mereka cenderung melakukan sesuatu dengan hati-hati dan tidak mudah percaya dengan kata hati. kepribadian juga berperan besar dalam kejadian gangguan jiwa pada seseorang (Fadli, 2016).

c. Faktor sosial budaya

1) Pekerjaan

Faktor status sosioekonomi yang rendah menjadi penyumbang terbesar adanya gangguan jiwa dan menyebabkan perilaku agresif dibandingkan dengan pada seseorang yang memiliki tingkat perekonomian tinggi. Hasil penelitian sebelumnya menyatakan bahwa kemiskinan dan kesehatan mental ditemukan bahwa terdapat perbedaan risiko untuk mengalami gangguan jiwa antara kelompok utama yang diukur dari strata sosial dan kemiskinan (Townsend, 2014). Pada golongan dengan status sosioekonomi yang rendah lebih rentan terhadap masalah kesehatan jiwa. Seseorang yang tidak memiliki pekerjaan mempengaruhi kejadian perilaku kekerasan, masalah status sosioekonomi yang rendah berdampak pada status kesehatan jiwa seseorang dan berpotensi menyebabkan gangguan jiwa dan menyebabkna perilaku agresif atau risiko perilaku kekerasan (Keliat, 2003).

Penelitian ini partisipan mengalami risiko perilaku kekerasan karena adanya tuntutan masalah dari pekerjaannya yang yaitu mendapatkan gaji yang rendah namun dengan beban kerja yang tinggi. Rendahnya tingkat sosial ekonomi atau kemiskinan, berhubungan dengan ketersediaan informasi dalam pemenuhan kebutuhan sehari-hari dan pemenuhan kebutuhan yang lain termasuk pelayanan kesehatan. Kondisi seperti ini akan menyebabkan keterbatasan dalam penyelesaian masalah dan akhirnya merasa frustasi dengan kondisinya serta merasa iri jika melihat kemampuan yang dimiliki orang lain, seseorang merasa malu dan marah pada diri sendiri, orang lain dan lingkungan (Nurwiyono, 2014).

\section{2) Pernikahan}

Penderita risiko perilaku kekerasan yang dirawat dengan gangguan jiwa memiliki riwayat status perkawinan hampir setengahnya belum menikah atau bercerai. Status perkawinan dapat dikaitkan dengan adanya teman dekat yakni pasangan dalam suka dan duka, yang menjadi pendukung atau penyemangat bagi partisipan (Stuart, 2009). Tidak terpenuhinya atau kegagalan dalam memenuhi tugas perkembangan pada masa perkawinan merupakan stresor bagi individu. Rasa malu dan marah dapat menimbulkan frustasi bagi penderita sehingga mengakibatkan penderita cenderung mengalami perilaku maladaptif (Nurwiyono, 2014).

Berdasarkan hasil wawancara, terdapat 1 partisipan pada penelitian ini yang mengalami masalah status perkawinan yaitu perceraian. Kegagalan dalam membina hubungan rumah tangga akan memberikan stresor bagi individu yang berujung pada perilaku kekerasan yang dilakukan oleh partisipan. Partisipan mengalami kesedihan dengan kondisi pada dirinya sendiri dan merasa iri jika melihat orang lain pacaran atau menikah, partisipan merasa malu dan marah pada diri sendiri, orang lain dan lingkungan (Nurwiyono, 2014).

\section{Faktor presipitasi}

a. Faktor biologis

Berdasarkan hasil wawancara, terdapat 2 partisipan yang mengungkapkan bahwa selama di rumah tidak rutin meminum obat. Penyakit yang tidak terkontrol, putus obat, 
kecemasan karena kegagalan dalam mengerjakan sesuatu akan menimbulkan perilaku kekerasan (Stuart, 2005). Penyakit yang tidak terkontrol dan putus obat akan menyebabkan ketidakseimbangan kembali komponen kimia dalam otak yang akhirnya memicu kembali individu utuk melakukan perilaku kekerasan. Hal ini menjelaskan bahwa peran obat disini penting dalam mengontrol perubahan-perubahan kimia yang terjadi didalam otak sehingga pemantauan akan penggunaan obat sangat diperlukan dalam mengatasi perilaku kekerasan.

Frekuensi masuk rumah sakit pada pasien perilaku kekerasan rata-rata pernah dirawat lebih dari 2 kali. Waktu atau lamanya terpapar stessor akan berdampak terhadap adanya keterlambatan dalam mencapai kemampuan dalam kemandirian pasien (Stuart, 2013). Kepatuhan pengobatan merupakan tantangan utama dalam perawatan pasien dengan skizofrenia sehingga dapat mengurangi kejadian masuk rumah sakit. Seringnya mengalami kekambuhan membuat kondisi pasien semakin bertambah parah karena setiap mengalami penurunan kemampuan sehingga berpengaruh terhadap fungsi kualitas hidup pasien. Kualitas hidup dan fungsi sosial merupakan hal utama yang harus diperhatikan pada pasien gangguan jiwa (Galupi, 2010). Berdasarkan penjelasan diatas dapat dilihat bahwa pentingnya menjaga kepatuhan pasien terhadap pengobatan gangguan jiwa untuk mencegah kekambuhan dan perawatan berulang di rumah sakit guna meningkatkan fungsi pasien dalam kehidupan keluarga dan bermasyarakat.l

\section{b. Faktor psikologis}

Kondisi pasien yang tidak diterima oleh lingkungan sekitar sebagai salah penyebab pasien melakukan tindakan resiko perilaku kekerasan. Senada dengan Teori psikoanalitik, teori ini menjelaskan tidak terpenuhinya kepuasan dan rasa aman dapat mengakibatkan tidak berkembangnya ego dan membuat konsep diri yang rendah. Agresif dan kekerasan dapat memberikan kekuatan dan meningkatkan citra diri (Nuraenah, 2012: 30). c. Faktor sosial budaya

Pada umumnya seseorang akan marah apabila dirinya merasa terancam, baik berupa kekerasan secara fisik, psikis maupun ancaman terhadap konsep dirinya. Seseorang akan mengalami peningkatan emosional jika mendapatkan penghinaan, kekerasan, kehilangan seseorang yang berarti, konflik dengan teman maupun keluarga, dan ketika merasa terancam baik permasalahan internal maupun eksternal (Hardiyanti, 2016). Konflik lingkungan ini sering menjadi salah satu faktor presipitasi bagi penderita untuk kembali dirawat di Rumah Sakit Jiwa atau meningkatkan kekambuhan risiko perilaku kekerasan seseorang. Kondisi seseorang seperti kelemahan fisik (penyakit fisik), keputusasaan, ketidakberdayaan, percaya diri yang kurang dapat menjadi penyebab perilaku kekerasan. Berbeda dengan kritikan yang mengarah pada penghinaan, kehilangan orang yang dicintai atau pekerjaan dan kekerasan merupakan faktor penyebab dari risiko peralaku kekerasan (Hardiyanti, 2016).

Berdasarkan hasil wawancara terdapat 2 partisipan yang mengalami konflik lingkungan yaitu berkelahi dengan teman, mendapatkan penghinaan dari teman, dan konflik dengan keluarga. Interaksi sosial yang provokatif dan konflik lingkungan dapat memicu timbulnya perilaku kekerasan (Hardiyanti, 2016). Pengalaman sosial yang tidak menyenangkan seperti mendapatkan kritikan yang mengarah penghinaan, interaksi sosial yang provokatif atau konflik, dan sulit memperhatikan hubungan interpersonal dapat mempengaruhi mencetuskan perilaku kekerasan terjadi kembali (Afifah, 2017).

\section{SIMPULAN DAN SARAN Simpulan}

Ada 3 Faktor predisposisi pada Pasien dengan Risiko Perilaku Kekerasan di RSJD Dr. Amino Gondohutomo Provinsi Jawa Tengah yaitu : Faktor genetik yang menyebabkan pasien mengalami risiko perilaku kekerasan. Faktor psikologis yang menyebabkan pasien mengalami risiko perilaku kekerasan antara lain yaitu: Kepribadian yang tertutup, Kehilangan, Aniayaseksual, Kekerasandalamkeluarga. Faktor sosial budaya yang menyebabkan 
pasien mengalami risiko perilaku kekerasan yaitu: Pekerjaan, Pernikahan.

Ada 3 Faktor Presipitasi pada Pasien dengan Risiko Perilaku Kekerasan di RSJD Dr. Amino Gondohutomo Provinsi Jawa Tengah yaitu; faktor genetik; Putus obat sebagai pencetus pasien mengalami resiko perilaku kekerasan. Faktor psikologis yaitu Konsep diri; tidak diterima lingkungan sekitar sebagai pencetus pasien mengalami risiko perilaku kekerasan. Faktor sosial budaya yaitu ketidakharmonisan lingkungan tempat tinggal membuat diri ingin marah dan berbicara dengan kasar.

\section{Saran}

Bagi pasien yang memiliki faktor predisposisi, erpikir positif bahwa didalam dirinya ada gen yang menyebabkan resiko perilaku kekerasan, menceritakan kepada profesional tentang permasalahan yang dihadapi, membina keluarga dengan harmonis lewat memahami peran dan fungsi dari tiap anggota keluarga. Bagi pasien yang memiliki faktor presipitasi, kesadaran pada pasien bahwa pasien masih membutuhkan terapi yang salah satunya adalah obat untuk mengontrol rasa marah, membantu pasien untuk mampu memahmi orang lain bukan dipahami orang lain.

\section{DAFTAR PUSTAKA}

Ashturkar,M.D., \&Dixit,J.V.(2013).Selected Epidemiological Aspects of Schizophrenia: Across Sectional Study At Terityary Care Hospital Maharashra. National Journal of Community Medicine, 65-69

Damaiyanti, Mukhripah\&Iskandar (2012) AsuhanKeperawatanJiwa. Bandung. PT.RefikaAditama.

DinkesJateng

ProfilKesehatanJiwaJawa Tengah.74.

EkoPrabowo

Konsep\&AplikasiAsuhanKeperawatan Jiwa. Yogyakarta, NuhaMedika.

\footnotetext{
Keliat BA \&Akemat (2009) Model PraktekProfesionalJiwa. Jakarta. PenerbitBukuKedokteran EGC.
}

Keliat BA, Akemat\& Helena C.D, Nurhaeni, $\mathrm{H}$

KeperawatanKesehatanJiwaKomunitas :CMHN (Basic Course) Jakarta : PenerbitBukuKedokteran EGC.

Kemenkes RI (2013) RisetKesehatanDasar (Riskesdas) 2013, LaporanNasional 2013.

Nurheni $\mathrm{H}$

KeperawatanKesehatanJiwa : CMHN, Jakarta, EGC

Saputri,A.I

(2016).

AnalisisFaktorPredisposisi Dan

PresisipitasiGangguanJiwa di

RuangInstalasiGawatdarurat RSJD

Surakarta, NaskahPublikasi, 1-11. Diterimadarihttp://eprints.ums.ac.id/44 990/

Saseno\&Kriswoyo PG (2013) PengaruhTindakan Restrain denganmansetterhadapSkizofrenia .JurnalKeperawatanMersi, 4 (2)

Subagyo,W.,Wahyuningsih,D,„\&Mukhad,M. (2013) Stres Management Of Client With Mental Disorder After Hospitalization. JurnalRisetKesehatan Vol 2,No 1 (ISSN:2252-5068 eISSN:2461-1026),288-291

Waters, F (2014). Schizophrenia. Retrieved Desember 20, 2017, from http://www.psychiatrictimes.com/schiz ophrenia/auditory-hallucinations-adultpopulations.

WHO. (2017, Februari 23). Mental Disorders. Retrieved April 03,2017, from

http://www.who.int/mental_health/ma nagement/depression/prevalence glob al_helath_estimates/en/.

Wibowo,S (2016) PenderitaGangguanJiwa di Jawa Tengah Terus Meningkat. Retrieved April 18,2017,fromTempo.co:http://gaya.te mpo.co/read 811005/peneritagangguan-jiwa-di-jawa-tengah-terus- 
Jurnal Ilmu Keperawatan Jiwa Volume 2 No 3, Hal 149-156, November 2019

Persatuan Perawat Nasional Indonesia Jawa Tengah

meningkat. Diaksespadatanggal 23

April 2017

Yosep. L. Puspawati,N.N., \&Sirait,A. (2017) PengalamanTraumatikiPenyebabGang guanJiwa ( Skizofrenia) Pasien di RSJ Cimahi .MajalahKedokteran Bandung Volume 41 No.4 tahun 2009 http://dx.doi.org/10.15395/mkb.v41n4. $\underline{253,194-200}$ 